\title{
Induction of L-form Bacteria from Bacillus thuringiensis
}

\author{
P. W. H. K. P. Daulagala ${ }^{1}$ and E. J. Allan ${ }^{2}$ \\ ${ }^{1}$ Department of Botany, Faculty of Natural Sciences, Kandy Regional Centre, The Open University of Sri \\ Lanka, Polgolla, Sri Lanka. \\ ${ }^{2}$ School of Biological Sciences, University of Aberdeen, Aberdeen, AB24 3UU, Scotland, United \\ Kingdom. \\ Accepted 12 October 2012
}

\begin{abstract}
Induction of L-form bacteria from Bacillus thuringiensis was investigated with the long-term view of their use as targeted biological control agents within plants. L-forms were successfully induced from $B$. thuringiensis subspecies israelensis 36-3 by preparing pour plates of exponential cultures in L-phase medium (LPM) containing $175 \mu \mathrm{g} \mathrm{ml}^{-1}$ cephalosporin C. The induced L-forms were then subcultured and maintained in L-phase medium supplemented with inactivated mycoplasma screened 5\% (v/v) horse serum (5HS) with a combination of $225 \mu \mathrm{g} \mathrm{ml}^{-1}$ cephalosporin $\mathrm{C}$ and $0.6 \mathrm{mg} \mathrm{ml}^{-1}$ penicillin $\mathrm{G}$, using the push block method. Induced L-forms showed typical features with pleiomorphic cells that contained granular particles and small vacuoles but no parasporal bodies. These L-forms were capable of growing on solidified media but failed to grow in liquid media.
\end{abstract}

Key words: bacterial L-forms, L- phase medium, inducing agents, cephalosporin, penicillin

\section{INTRODUCTION}

Bacterial L-forms may be defined as a special type of growth derived or induced from a bacterium following suppression of the rigid cell wall (Madoff, 1986). They were originally isolated from natural sources but nowadays are mainly induced artificially by treatment of parental cell-walled bacteria with different cell wall inhibiting agents such as penicillin and lysozyme (Madoff, 1986). During induction of L-form bacteria, classical parental bacterial forms are generally replaced by spherical or pleiomorphic granular cells which are commonly larger than the parental forms from which they are derived (Madoff, 1986).

It is accepted that the induction and subsequent cultivation of $\mathrm{L}$-forms is difficult. The induction process depends on identifying cell wall inhibitors with respect to their type and concentration. Concomitant with this, newly induced L-forms are prone to reversion to the cell-walled form (i.e. they are unstable) requiring frequent observation and subculture to maintain the L-form state (Allan et al., 2009). Compounding this, the physical state of the medium e.g. gel strength can also affect induction and growth. Experience by the Aberdeen Group (i.e. Paton and Allan) have indicated that the concentration of inhibitors often has to be altered during the induction process and that in some scenarios, the use of two inhibitors is more effective at maintaining the L-form state.

An interesting aspect of L-form bacteria is that they form symbioses with plants including French dwarf bean (Amijee et al., 1992; Paton and Innes, 1991), Chinese cabbage (Waterhouse et al., 1994; Daulagala and Allan, 2003) and strawberry (Ferguson et al., 2000). The symbiosis has the potential for offering biological control of plant diseases. A major advantage of using L-form bacteria compared to their cell-walled form, is that their pleiomorphic morphology will allow access to small spaces such as the extracellular spaces within plant tissue or even intercellularly as shown for the symbiosis between Pseudomonas syringae pv. phaseolicola L-forms and bean (Paton and Innes, 1991). It can be postulated that this would target the biocontrol agent in the arena of disease and would aid in the long-term persistence of the biocontrol agent. In addition, and significantly, plants treated with L-form bacteria have been shown to be protected from subsequent attack by both bacterial (Amijee et al., 1992) and fungal (Walker et al., 2002; Daulagala and Allan, 2003) pathogens. The mode of action of L-form bacteria as a biocontrol agent remains unclear with both antibiosis (Amijee et al., 1992; Walker

*Corresponding author's email: pdaulagala@yahoo.com 
et al., 2002) and induced resistance (Daulagala and Allan, 2003) being suggested.

The bacterium Bacillus thuringiensis $(B t)$ is rodshaped, Gram-positive, crystalliferous and spore-forming. When cultured under suitable conditions, it sporulates and forms a crystalline parasporal body containing delta-endotoxins. When sporulation is complete, the bacterial cell wall disintegrates and releases spores and crystals into the surrounding medium. When the crystals are ingested by susceptible insect larvae, they are solubilized by alkaline gut juices of the insect, releasing potent delta-endotoxins. These activated toxins severely damage the insect gut cells. Few subspecies of $B$. thuringiensis are used in commercial production of crystals. $B t$ subspecies kurstaki is active against lepidopterous pests and is used in all commercial products applied on Canadian forests (Cunningham and van Frankenhuyzen, 1991). $B t$ subspecies israelensis is used against Diptera, particularly for control of aquatic larvae of blackflies and mosquitoes (Lacey and Merritt, 2003). Bt subspecies tenebrionis is effective against some species of Coleoptera and has been used mainly on Colorado potato beetle, Leptinotarsa decemlineata (Rahardja and Whalon, 1995).

L-forms have been obtained from both Grampositive and Gram-negative species as well as filamentous bacteria such as Streptomyces hygroscopicus (Hoischen et al., 1997) and Streptomyces viridifaciens (Innes and Allan, 2001). Induction of L-forms from several species of Bacillus including $B$. subtilis, $B$. licheniformis, B. pumilus and B. megaterium has been reported (Gumpert and Taubeneck, 1983). As there is no record of L-form induction from B. thuringiensis, this preliminary study was basically focused only on induction of L-forms from $B$. thuringiensis.

\section{MATERIALS AND METHODS}

\section{Organisms and media}

Four different isolates of $B$. thuringiensis subsp. israelensis and aizawai were used as the parental sources for the induction of L-form bacteria namely, Bt aizawai HD133, Bt aizawai T7002, Bt israelensis 36-3 and Bt israelensis IPS78.

For all induction purposes, cell-walled forms were grown in Bacillus Growth Medium (BGM) (Kusaka, 1967). This contained (g/l): glucose, 20.00; yeast extract, 2.5 and casamino acid or casein hydrolysate (Oxoid), 25. The $\mathrm{pH}$ was adjusted to 7.0 before autoclaving at $121{ }^{\circ} \mathrm{C}$ for 15 min. L-phase Medium (LPM) and L-phase Broth (LPB) were used in induction of L-forms and further subculture of induced L-forms. Lphase Medium contained (g/l): glucose, 5; yeast extract, 5; peptone, 5; $\mathrm{MgSO}_{4} .7 \mathrm{H}_{2} \mathrm{O}, 0.1$; agar (Oxoid No. 1) 7.5 and sucrose, 200. This medium was supplemented with $5 \%$ (v/v) mycoplasma-screened horse serum (5HS) (Gibco). LPB contained all above ingredients except agar. The $\mathrm{pH}$ was adjusted to 7.0 before autoclaving at $121{ }^{\circ} \mathrm{C}$ for $15 \mathrm{~min}$. Liquid L-form cultures in LPB were incubated in an orbital incubator (Gallenkamp, UK) at $60 \mathrm{rpm}$ at $30{ }^{\circ} \mathrm{C}$. Solidified LPM plates were incubated at $30{ }^{\circ} \mathrm{C}$.

\section{Screening for inducing agents}

The effectiveness of different agents for inducing L-forms was tested against the cellwalled forms by using an agar diffusion method. Overnight liquid cultures of $B$. thuringiensis isolates were inoculated into fresh BGM flasks and incubated (150 rpm shaking, $\left.30{ }^{\circ} \mathrm{C}\right)$. The cells grown for 4-5 h in BGM were harvested at $1500 \mathrm{~g}$ for $10 \mathrm{~min}$ (Chillspin, UK). The pellets were resuspended in $5 \mathrm{ml} \mathrm{BGM}$ to obtain a thick cell suspension. A set of seven plates containing LPM + 5HS medium were surface seeded with each isolate. The plates were surface dried and a central well was cut in each plate using a sterile cork borer (10 $\mathrm{mm}$ diameter). Each well was filled to capacity $(\sim 200 \mu \mathrm{l})$ with filter sterilized (0.2 $\mu \mathrm{m}$ Acrodisc) aqueous solutions of phosphomycin (Sigma, UK), $10 \mathrm{mg} \mathrm{ml}^{-1}$; vancomycin (Sigma, UK), $10 \quad \mathrm{mg} \mathrm{ml}^{-1}$; bacitracin (Sigma, UK), $10 \mathrm{mg} \mathrm{ml}^{-1}$; cephalosporin C (Sigma, UK), $10 \mathrm{mg} \mathrm{ml}^{-1}$; penicillin $\mathrm{G}$ (Crystapen, Glaxo, UK), $10 \mathrm{mg} \mathrm{ml}^{-1}$ and lysozyme (Sigma, UK), $50 \mathrm{mg} \mathrm{ml}^{-1}$. Sterile distilled water $(\sim 200 \mu \mathrm{l})$ was used for the control plates. The diameter and the appearance of inhibition zones were recorded after overnight incubation at $30^{\circ} \mathrm{C}$. The growth at edges of each zone was examined using a Polyvar microscope (Reichert-Jung, Austria) with phase and interference contrast microscopy for protoplasts and L-form-like cells. Photographs were taken with a Konica FT-1 automatic $35 \mathrm{~mm}$ camera connected to a Reichert-Jung photographic control unit.

Having obtained the best indication of L-form induction from $\mathrm{Bt}$ israelensis 36-3, it was used for further work. Cephalosporin $\mathrm{C}$ (the most effective antibiotic) and bacitracin (the second most effective antibiotic) were used as inducing agents. 
Induction of Bt subsp. israelensis 36-3 Lforms with cephalosporin and bacitracin Initial induction experiments were carried out in both liquid LPB and solidified LPM media supplemented with 5HS and 500, 50 and $5 \mu \mathrm{g}$ $\mathrm{ml}^{-1}$ of cephalosporin C. Both spread and pour plates were prepared using $100 \mu \mathrm{l}$ inoculum from an overnight culture of Bt israelensis 36-3 grown in BGM while $25 \mathrm{ml}$ liquid cultures were similarly inoculated. The experiment was replicated using the same concentrations of bacitracin. To determine the effect of combination of antibiotics, $250 \mu \mathrm{g} \mathrm{ml}$ bacitracin plus $250 \mu \mathrm{g} \mathrm{ml}^{-1}$ cephalosporin $\mathrm{C}$ and $25 \mu \mathrm{g} \mathrm{ml}{ }^{-1}$ bacitracin plus $25 \mu \mathrm{g} \mathrm{ml} \mathrm{ml}^{-1}$ cephalosporin $\mathrm{C}$ were also used in both solidified (as spread and pour plates) and liquid media. Cultures were examined daily using a Polyvar microscope (Reichert-Jung, Austria).

Microscopic observations revealed that cephalosporin $\mathrm{C}$ had a better effect on $\mathrm{L}$-form induction in solidified medium, than either the combination of both cephalosporin $\mathrm{C}$ plus bacitracin or bacitracin alone. Therefore, to select the best cephalosporin concentration, the above experiment was repeated using LPM + 5HS medium supplemented with different concentrations of cephalosporin C (400, 300, 200, 175, 150 and $125 \mu \mathrm{g} \mathrm{ml}^{-1}$ ) using both pour and spread plates. Plates were observed daily for growth/L-form induction and if necessary, subculturing was done as required.

\section{Subculture of induced L-forms}

Attempts to subculture induced L-forms were made on both solidified and liquid media. Push block method (Madoff and Pachas, 1976) and streaking were used on solidified media. Since the best L-form induction had been achieved at $175 \mu \mathrm{g} \mathrm{ml}^{-1}$ of cephalosporin $\mathrm{C}$, this concentration and a slightly higher concentration $\left(200 \mu \mathrm{g} \mathrm{ml}^{-1}\right)$ were used for initial subculture. The blocks were pushed along the medium at frequent intervals providing a fresh area and medium for the L-forms to grow. After a few pushes, an agar block supporting the derived growth was transferred onto fresh LPM + 5HS or into LPB+ 5HS media containing 175 or 200 $\mu \mathrm{g} \quad \mathrm{ml}^{-1}$ cephalosporin $\mathrm{C}$ as required. Occasionally cephalosporin was used at higher concentrations $400-500 \mu \mathrm{g} \mathrm{ml}^{-1}$ in an attempt to maintain the growth of induced L-form state. At regular and frequent intervals, the morphology of the developing growth was examined microscopically with particular attention being made for any signs of reversion. Streaked plates (initially a few parallel lines over a small area of agar) where L-forms still persisted were selected and a small amount of the existing growth was streaked to an uninoculated area of the same plate and re-incubated (Innes, 1993).

In an attempt to obtain L-form growth in liquid media, agar blocks supporting L-form growth were excised aseptically from push block plates and transferred to $100 \mathrm{ml}$ flasks containing 25 $\mathrm{ml}$ LPB +5 HS supplemented with either 175 or $200 \mu \mathrm{g} \mathrm{ml}^{-1}$ cephalosporin $\mathrm{C}$. The cultures were incubated at $30{ }^{\circ} \mathrm{C}$ on a Gallenkamp orbital incubator at $60 \mathrm{rpm}$. Rapid reversion proved challenging when cultivating induced L-forms in both liquid and solidified media. If reversion occurred, either the level of cephalosporin $\mathrm{C}$ was further raised slightly $\left(225 \mu \mathrm{g} \mathrm{ml}^{-1}\right)$ and used with combination of bacitracin and penicillin $G$ or a smaller volume of inoculum was used with the same initial concentration of cephalosporin C. Observations and subculture frequency were also increased.

\section{RESULTS}

\section{Screening for inducing agents}

Inhibition zones were observed in all surface seeded LPM + 5HS plates with the four $B$. thuringiensis isolates after overnight incubation. Cells from the border of each inhibition zone were examined microscopically and the percentages of L-form-like cells, pleiomorphic cells and normal rods were estimated for all four isolates with each different inducing agent tested. Bt israelensis 36-3 showed the best signs of L-form induction with approximately $65 \%$ and $35 \%$ L-form-like cells with cephalosporin $\mathrm{C}$ and bacitracin respectively (Table 1). Therefore, from all four isolates, $B t$ israelensis 36-3 was selected for further work.

\section{Induction of $\mathrm{Bt}$ israelensis 36-3 L-forms with} cephalosporin $\mathrm{C}$ and bacitracin

Microscopic observations revealed that on solidified medium, cephalosporin $\mathrm{C}$ had more effect on L-form induction, than either the combination of both cephalosporin $\mathrm{C}$ and bacitracin or bacitracin alone. Higher percentages of L-form-like cells and pleiomorphic cells were obtained in pour plates where cephalosporin $\mathrm{C}$ was incorporated as the sole inducing agent. Although it required longer incubation, the percentages of L-form-like cells and pleiomorphic cells indicated that the induction on pour plates was better than that of spread plates. 
Table 1. Occurrence of the different cell types at inhibition zone edges produced by Bt israelensis 36-3 with different inducing agents

\begin{tabular}{lcl}
\hline Inducer & $\begin{array}{c}\text { Concentration } \\
\left(\mathbf{~ m g ~ m}^{\mathbf{- 1}}\right)\end{array}$ & $\begin{array}{c}\text { Cell morphology at zone edge and the occurrence of L- } \\
\text { form like cells (per field of observation) }\end{array}$ \\
\hline $\begin{array}{l}\text { Bacitracin } \\
\text { Phosphomycin }\end{array}$ & 10 & $\begin{array}{l}\text { Rods, pleiomorphic cells and 35\% L-form-like cells } \\
\text { Rods, occasional pleiomorphic cells and 20\% L-form-like } \\
\text { cells }\end{array}$ \\
Vancomycin & 10 & $\begin{array}{l}\text { Majority of rods and 5\% L-form-like cells } \\
\text { Cephalosporin C }\end{array}$ \\
$\begin{array}{l}\text { Penicillin G } \\
\text { Lysozyme }\end{array}$ & 10 & $\begin{array}{l}\text { Predominantly rods and 10\% L-form-like cells } \\
\text { Predominantly rods and 25\% L-form-like cells }\end{array}$ \\
\hline
\end{tabular}

Table 2. Occurrence and the description of cell morphology in pour plates supplemented with different concentrations of cephalosporin $\mathrm{C}$

\begin{tabular}{|c|c|c|c|}
\hline \multirow{2}{*}{$\begin{array}{l}\text { Concentration of } \\
\text { cephalosporin } \mathrm{C} \\
\left(\mu \mathrm{g} \mathrm{ml}^{-1}\right)\end{array}$} & \multicolumn{3}{|c|}{ Occurrence (per field of observation) and morphology of } \\
\hline & L-form-like cells & Pleiomorphic cells & Normal rods \\
\hline 125 & $\begin{array}{l}40 \% \text {; Variable sizes. Have vacuoles } \\
\text { and granules. }\end{array}$ & $\begin{array}{l}40 \% \text {; Many as short } \\
\text { oval shaped rods }\end{array}$ & $20 \%$ \\
\hline 150 & $\begin{array}{l}50 \% \text {; Different sizes with vacuoles } \\
\text { and granules. }\end{array}$ & $\begin{array}{l}45 \% \text {; Highly } \\
\text { pleiomorphic }\end{array}$ & $5 \%$ \\
\hline 175 & $\begin{array}{l}\text { 95\%; Different sizes. Vacuoles and } \\
\text { granules present. }\end{array}$ & $\begin{array}{l}5 \% \text {; Highly } \\
\text { pleiomorphic }\end{array}$ & $0 \%$ \\
\hline 200 & 75\%; Many with no vacuoles. & $10 \%$ & $5 \%$ \\
\hline 300 & $65 \%$; More like protoplasts. & $10 \%$ & $5 \%$ \\
\hline 400 & $\begin{array}{l}40 \% \text {; No vacuoles in many. More } \\
\text { like protoplasts. }\end{array}$ & $20 \%$ & $10 \%$ \\
\hline
\end{tabular}

No good L-form induction was achieved in liquid medium. The overall results indicated that cephalosporin $\mathrm{C}$ concentration between 50 and $500 \mu \mathrm{g} \mathrm{ml}^{-1}$ was required for a successful induction of L-forms from Bt israelensis 36-3. Therefore, an experiment was carried out using a series of ten-fold concentrations ranging from 5 $\mu \mathrm{g} \mathrm{ml}^{-1}$ and $500 \mu \mathrm{g} \mathrm{ml}^{-1}$ cephalosporin C. Both spread and pour plates with lower concentration $\left(5 \mu \mathrm{g} \mathrm{ml}^{-1}\right)$ had more rods while the higher concentrations $\left(500 \mu \mathrm{g} \mathrm{ml}^{-1}\right)$ had more cell debris indicating cell death. When a series of concentrations from $125 \mu \mathrm{g} \mathrm{ml}^{-1}$ to $400 \mu \mathrm{g} \mathrm{ml}^{-1}$ cephalosporin $\mathrm{C}$ was used in pour and spread plates, results from pour plates showed good levels of induction with the highest percentage of L-form-like cells with $175 \mu \mathrm{g} \mathrm{ml}{ }^{-1}$ cephalosporin C (Table 2, Figure 1). Approximately $10 \%$ and $20 \%$ cell debris indicating cell death were found in cultures on plates supplemented with $200 \mu \mathrm{g} \mathrm{ml}^{-1}$ and 300 $\mu \mathrm{g} \mathrm{ml}^{-1}$ cephalosporin $\mathrm{C}$ respectively.

Pour plates with $175 \mu \mathrm{g} \mathrm{ml}^{-1}$ cephalosporin $\mathrm{C}$, showed an excellent L-form growth after 7 days of incubation at $30{ }^{\circ} \mathrm{C}$ (Figure 1c). L-forms were much more varied in size. The bigger Lforms contained a few small vacuoles and were highly granulated. When this induction method was repeated, good L-form cultures were always obtained with $100 \%$ L-form growth. When this set of plates was incubated further, reversion occurred with only approximately $5 \%$ of Lforms surviving after another 2 days of incubation. Indeed they could hardly be observed among the rods because L-form colonies quickly became overgrown by revertants.

\section{Subculture of induced L-forms}

Even although the induction had, in initial experiments, not been successful in liquid cultures, subculturing of the L-forms obtained on $\mathrm{LPM}+5 \mathrm{HS}$ with $175 \mu \mathrm{g} \mathrm{ml}^{-1}$ cephalosporin $\mathrm{C}$, was attempted in both solidified (push block and streak plates) and liquid media in order to maintain a good growth of L-forms. 

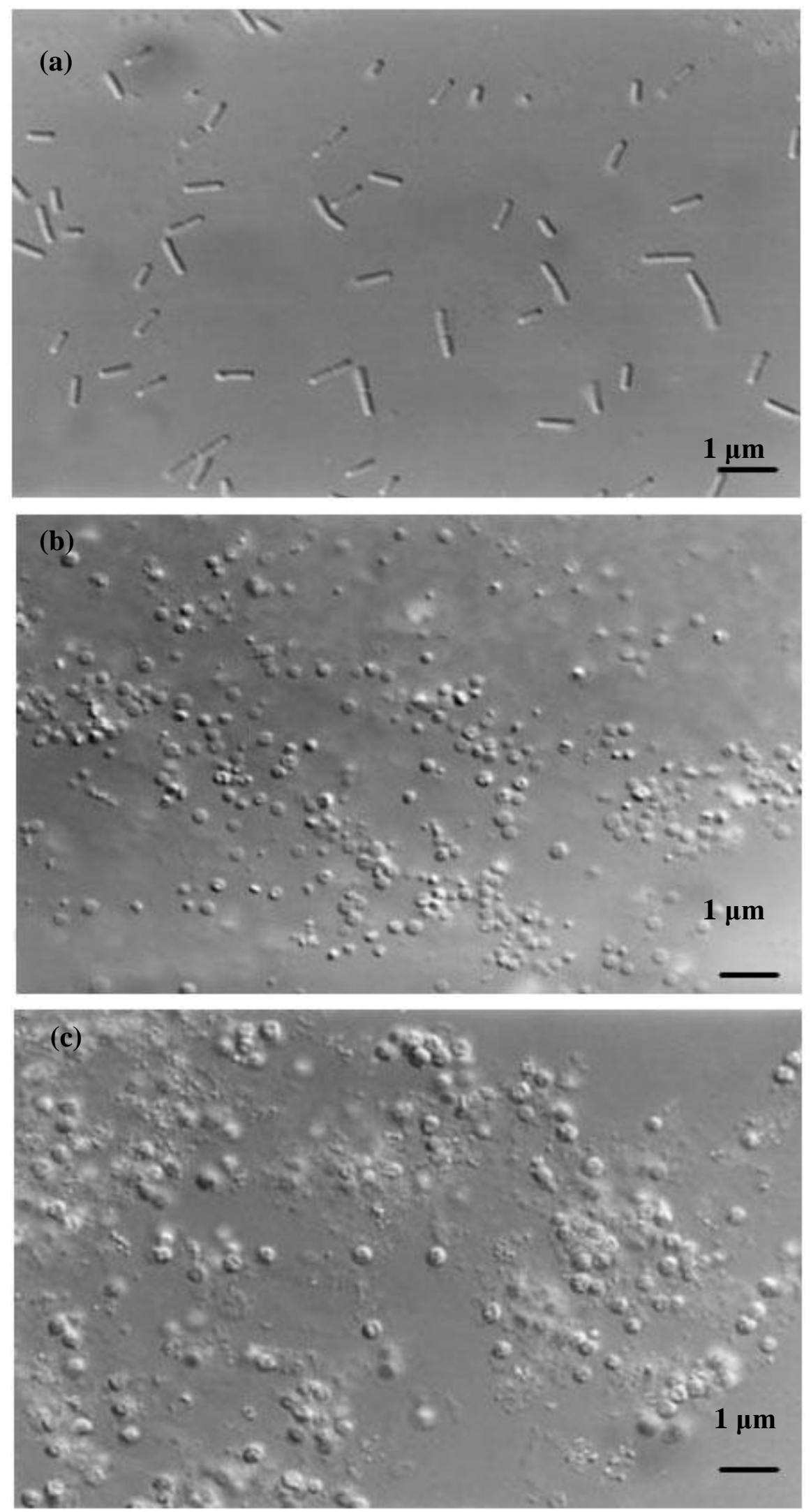

Figure 1- Different stages of L-form induction of B. thuringiensis israelensis (a) Cell-walled form on Nutrient Agar plates. (b) L-forms on LPM + 5HS plate supplemented with $175 \mu \mathrm{g} \mathrm{ml}^{-1}$ cephalosporin C, after 4 days of incubation at $30^{\circ} \mathrm{C}$. (c) A 7 day incubated plate showing L-form growth. Note the larger size of the cells and granulation (Interference microscopy). 
Before subculture, the older and younger regions of growth derived from pushed agar blocks were confirmed to contain mostly L-forms (occasionally a cell walled form could be observed). Unfortunately subculture on both media types, supplemented with 175 and $200 \mu \mathrm{g}$ $\mathrm{ml}^{-1}$ cephalosporin $\mathrm{C}$, resulted in a high level of reversion.

As another option, combinations of antibiotics were used. Thus, instead of using a high concentrations of cephalosporin alone (e.g. 500 $\mu \mathrm{g} \mathrm{ml}^{-1}$ cephalosporin $\mathrm{C}$ which resulted in more cell debris in plates suggesting that cell death was occurring), the initial concentration of cephalosporin $C$ was slightly increased (i.e. 225 $\mu \mathrm{g} \mathrm{ml}^{-1}$ ) and used in combination with bacitracin (which had showed some promise in the earlier inhibition zone assays, Table 1) and penicillin (used routinely for Gram positive protoplast/Lform induction, Strang, 1992).

Liquid cultures and streak and push block plates were all examined for continued L-form growth. It was anticipated that L-forms derived from $\mathrm{LPM}+5 \mathrm{HS}$ plates with $175 \mu \mathrm{g} \mathrm{ml} \mathrm{m}^{-1}$ cephalosporin would subculture well onto the same medium but quick reversion occurred in both streak, push block plates and in liquid media. Raising the cephalosporin concentration (200 and even to $400 \mu \mathrm{g} \mathrm{ml}^{-1}$ ) also resulted in a poor growth but the combination of $225 \mu \mathrm{g} \mathrm{ml}^{-1}$ cephalosporin $C$ with $0.6 \mathrm{mg} \mathrm{ml}^{-1}$ penicillin $\mathrm{G}$ resulted in greater numbers of L-forms occurring in both actively growing and older areas of the pushed agar block. Cells remained as L-forms for longer with no reversion being seen. Cultures were maintained, by subculture, with this combination of antibiotics for approximately two months. Over this period, push blocks had initially to be moved daily but with time this was reduced to 2-3 day intervals. Blocks supporting surface growth were moved onto fresh media as required (approximately weekly).

Throughout this work, numerous observations were made on Bt israelensis 36-3 L-form bacteria and on no occasion, in contrast to the parent cell walled form, spores were observed or indeed any crystalline parasporal bodies.

\section{DISCUSSION}

The initial research undertaken concerned the selection of inducing agents for the initiation of B. thuringiensis $\mathrm{L}$-forms with the choice of agents being made from those used routinely in the Aberdeen laboratory, particularly for Bacillus spp. Thus, the lytic enzyme lysozyme was the most effective inducing agent for initiation of Lforms from B. subtilis NCIMB 8054 (Allan, 1991) while cephalosporin proved successful for induction of B. brevis L-forms (Strang, 1992). Inhibition zone assays have previously been used with success for screening inducing agents (Strang, 1992) and in this work, the $\beta$-lactam antibiotic cephalosporin $\mathrm{C}$, produced the best induction of $B$. thuringiensis L-forms. Microscopic examination of the cells at the margins of the inhibition zones was straightforward with it being easy to distinguish the cell-wall deficient L-forms from the unaffected rods. This proved very useful in estimating the percentage of different cell types. L-forms were more pleiomorphic and contained granular particles and small vacuoles. The occurrence of vacuoles and small granular particles in stable protoplast-type L-forms of $B$. subtilis was also recorded by Oparka et al. in 1993.

The best induction of L-forms was obtained for Bt israelensis 36-3 using cephalosporin C and therefore further work was continued with this isolate in both liquid and solidified media. In every experiment carried out in liquid medium, a lower induction of L-forms and a higher percentage of rods was observed than when solidified medium was used. Moreover, the Lforms tended to revert very quickly in liquid medium. Maxted (1972) also reported that successful inductions of L-forms of many bacteria had been difficult in liquid media. Allan (1991) achieved L-forms of B. subtilis, which were successfully induced and grown in solidified LPM with lysozyme but could not be grown in liquid media. However, after a 3 month subculture on solidified media they were successfully introduced to liquid medium. After a further 19 weeks subculture, they could be grown in both media without the inducer (stable L-forms) showing the adaptation process typical of L-forms (Allan et al., 2009). In contrast, Lforms of B. licheniformis and B. subtilis induced by Wyrick and Rogers (1973) with methicillin were successfully grown in both liquid and solidified media. These results indicate that each L-form bacteria requires different conditions for their induction, growth and maintenance.

During induction of L-forms of Bt israelensis 36-3, $175 \mu \mathrm{g} \mathrm{ml}^{-1}$ cephalosporin $\mathrm{C}$ gave the best induction of cell walled form to L-form-like cells in solidified L-phase medium. In solidified 
medium, pour plates gave a better induction than surface spread plates. This may be due to improved contact of cells with cephalosporin C within the medium in pour plates.

In addition, media used for L-form induction and cultivation often contain inactivated mycoplasma-screened horse serum. It is believed that serum does not act as a growth factor, but that it neutralises the inhibiting substances in the medium (Maxted, 1972). Allan (1991) reported that horse serum was not required for the growth of stable $B$. subtilis Lforms, but the viable cell count was increased by a factor of 10 , when serum was incorporated into the plate count medium. In this study there was no improvement in the quality of L-form growth with either $5 \%$ or $10 \%$ HS.

All attempts of further subculture of induced Lforms of Bt israelensis 36-3 indicated the difficulty in maintaining them both in liquid and solid media with individual or combinations of inducing agents. Although, $100 \%$ of the population was induced to $\mathrm{L}$-forms in pour plates, due to the poor L-form growth and rapid reversion, there was not enough material to continue further subculture of these cells. During subculture, the push block method yielded good $\mathrm{L}$-form growth. The combination of $225 \mu \mathrm{g} \mathrm{ml}^{-1}$ cephalosporin $\mathrm{C}$ with $0.6 \mathrm{mg} \mathrm{ml}^{-1}$ penicillin $\mathrm{G}$ resulted in greater numbers of $\mathrm{L}$-forms occurring in both actively growing and older areas of the pushed agar block. Under these conditions, even though there was a good L-form growth initially, successive subculture yielded a poor growth.

This work was undertaken with the longer term aim of using the L-forms as targeted biocontrol agents within plants. The successful induction of Bt israelensis 36-3 L-forms led to observations that these did not produce spores or the crystalline parasporal bodies, which contain the relevant endotoxins for insect pests. Although there are no reports of L-form bacteria producing spores there remains controversy over their production of secondary metabolites. Thus, Streptomyces hygroscopicus L-forms did not produce spores and secondary metabolites (Gumpert and Taubeneck 1983; Hoischen et al. 1997). In contrast, results presented by Innes \& Allan (2001) have shown that the stable L-forms of $S$. viridifaciens, which did not produce spores, were capable of secondary metabolite production but at much lower levels.

In conclusion, this work showed that L-form bacteria from isolate $B t$ israelensis 36-3 could be induced in pour plates directly using $175 \mu \mathrm{g}$ $\mathrm{ml}^{-1}$ cephalosporin $\mathrm{C}$ as an effective inducing agent. These induced L-forms were very unstable. Therefore further subculture was achieved using blocks of medium containing Lforms that were excised from pour plates and used as push blocks on medium containing two inducing agents i.e. $225 \mu \mathrm{g} \mathrm{ml}^{-1}$ cephalosporin $\mathrm{C}$ with $0.6 \mathrm{mg} \mathrm{ml}^{-1}$ penicillin G. These derived Lforms are, after two months in culture, much less prone to reversion and future work can progress in attempting to achieve stability.

\section{ACKNOWLEDGEMENTS}

Authors thank Ms. Carol Innes and Ms. Gail Rettie (technical staff, School of Biological Sciences, University of Aberdeen) for their assistance given throughout this study. Financial assistance by the Commonwealth Scholarship Commission is gratefully acknowledged. $B t$ israelensis IPS78 and Bt aizawai HD133 were kindly provided by Professor D.J. Ellar, University of Cambridge, United Kingdom. $B t$ aizawai T7002 and Bt israelensis 36-3 (isolated in Brazil) were obtained from Professor F. Priest, Heriot-Watt University, Edinburgh, Scotland, United Kingdom.

\section{REFERENCES}

Allan, E.J. (1991). Induction and cultivation of stable L-forms of Bacillus subtilis. Journal of Applied Bacteriology 70: 339-343.

Allan, E.J., Hoischen, C. and Gumpert, J. (2009). Bacterial L-forms. Advances in Applied Microbiology 68: 1-39.

Amijee, F., Allan, E.J., Waterhouse, R.N., Glover, L.A. and Paton, A.M. (1992). Nonpathogenic association of L-form bacteria (Pseudomonas syringae pv. phaseolicola) with bean plants (Phaseolus vulgaris L.) and its potential for biocontrol of halo blight disease. Biocontrol Science and Technology 2: 203-214.

Cunningham, J. C. and van Frankenhuyzen, K. (1991). Microbial insecticides in forestry. The Forestry Chronicle 67: 473-480.

Daulagala, P.W.H.K.P. and Allan, E.J. (2003). Lform bacteria of Pseudomonas syringae pv. phaseolicola induce chitinases and enhance resistance to Botrytis cinerea infection in Chinese cabbage. Physiological and Molecular Plant Pathology 62: 253-263.

Ferguson, C.M.J., Booth, N.A. and Allan, E.J. (2000). An ELISA for the detection of 
Bacillus subtilis L-form bacteria confirm their symbiosis in strawberry. Letters in Applied Microbiology 31: 390-394.

Gumpert, J. and Taubeneck, U. (1983). Characteristic properties and biological significance of stable protoplast type Lforms. In: I. Potrykus, C.T. Harms, A. Hinnen, R. Hutter, P.J. King and R.D. Shillito (Eds), Experienta Supplement 46, $6^{\text {th }}$ International Protoplast Symposium, Birkhäuser Verlag, Basel, pp 227-241.

Hoischen, C., Gura, K., Luge, C. and Gumpert, J. (1997). Lipid and fatty acid composition of cytoplasmic membranes from Streptomyces hygroscopicus and its stable protoplast type L-form. Journal of Bacteriology 179: 34303436.

Innes, C.M.J. (1993). An Investigation of L-form Development: The Induction, Cultivation and Growth of L-forms of Pseudomonas syringae pv. phaseolicola and Streptomyces viridifaciens. M.Sc. Thesis, University of Aberdeen.

Innes, C.M.J. and Allan, E.J. (2001). Induction, growth and antibiotic production of Streptomyces viridifaciens $\mathrm{L}$-form bacteria. Journal of Applied Microbiology 90: 301308.

Kusaka, I. (1967). Growth and division of protoplasts of Bacillus megaterium and inhibition of division by penicillin. Journal of Bacteriology 94: 884-888.

Lacey, L. A. and Merritt, R. W. (2003). The safety of bacterial microbial agents used for black fly and mosquito control in aquatic environments. In: H. M. T. Hokkanen and A. E. Hajek (Eds.) Environmental Impacts of Microbial Insecticides, Kluwer Academic Publishers, Dordrecht, The Netherlands, Pp. 151-168.

Madoff, S. (1986). Introduction to bacterial Lforms. In: S. Madoff (Ed) Bacterial L-forms, Marcel Dekker Inc., New York, pp 1-20.

Madoff, S. and Pachas, W.N. (1976). Mycoplasma and the L-forms of bacteria. In:
Rapid Diagnostic Methods in Medical Microbiology, Williams and Wilkins, Baltimore, pp 195-217.

Maxted, W.R. (1972). Specific procedures and requirements for the isolation, growth and maintenance of the L-phase of some microbial groups. In: J.R. Norris and G.W. Ribbons (Eds.), Methods in Microbiology vol.7A, Academic Press, London \& New York, 423-449.

Oparka, K.J., Wright, K.M., Murant, E.A. and Allan, E.J. (1993). Fluid-phase endocytosis: Do plants need it? Journal of Experimental Botany 44 (Suppl.): 247-255.

Paton, A.M. and Innes, C.M.J. (1991). Methods for the establishment of intracellular associations of L-forms with higher plants. Journal of Applied Bacteriology 71: 59-64.

Rahardja, U. and Whalon, M. E. (1995). Inheritance of resistance to Bacillus thuringiensis subsp. tenebrionis CryIIIA $\delta$ Endotoxin in Colorado potato beetle (Coleoptera: Chrysomelidae). Journal of Economic Entomology 88: 21-26.

Strang, J.A. (1992). Bacillus brevis Nagano Lforms: Induction, Cultivation and Potential Use as Biocontrol Agents. M.Sc. Thesis, University of Aberdeen.

Walker, R., Ferguson, C. M. J., Booth, N. A. and Allan, E.J. (2002). The symbiosis of Bacillus subtilis L-forms with Chinese cabbage seedlings inhibits conidial germination of Botrytis cinerea. Letters in Applied Microbiology 34: 42-45.

Waterhouse, R.N., Strang, J.A., Amijee, F., Tyson, R.H., Allan, E.J. and Glover, L.A. (1994). Molecular detection of Pseudomonas syringae pv. phaseolicola L-forms associated with Chinese cabbage. Microbial Releases 2: 273-279.

Wyrick, P.B. and Rogers, H.J. (1973). Isolation and characterization of cell-walled deficient variants of Bacillus subtilis and Bacillus licheniformis. Journal of Applied Bacteriology 116: 456-465. 